\title{
INVESTIGATION ON MEDICINAL VALUE OF POISONOUS PLANTS FROM BHANDARA DISTRICT.(M.S.)
}

\author{
Kapgate V.D, Qureshi Sayeda Parveen \\ Department of Botany, D.D. Bhoyar College, Mouda, Distt.Nagpur \\ P.G. Department of Botany, J.M.Patel College, Bhandara.(M.S.)
}

\begin{abstract}
Communicated : 22.12.19
Revision : 06.01.2020

Accepted : 26.01.2020

Published: 30.01.2020

ABSTRACT:

The main aim of the present study is to focus on the diversity of plants for further utility and conservation. Medicinal plants have been used for thousands of years, and many cultures depend on indigeneous medicinal plants for their primary health care needs. Various plants are very poisonous but such poisonous plants are used for treatment of various diseases are of significant value throughout the world. Poisonous medicinal plants are used for various ailments such as antidiabitic, anticancer, antibacterial, antifungal.
\end{abstract}

Key words: - Aliments, Cultures, Indigeneous, Poisonous.

\section{INTRODUCTION:}

Use of plants for the treatment of various human ailments is as old as human civilization. Even after the induction of 200 years of modern medicine, about $90 \%$ people in rural India take the help of local health practitioners for the treatment of various disease. At present about $65 \%$ of the Indian population is dependent on the traditional system of medicine. Various plants are very poisonous but such poisonous plants are used for treatment of various diseases are of significant value throughout the world. Among the plant diversity some of them have great poisonous but it have great potential to treat many diseases which are referred as medicinal plants. The main aim of the present study is to focus on the diversity of plants for further utility and conservation. Present paper is a useful account on poisonous plants that have medicinal value from the area of Bhandara region. A survey on plant diversity was made during 2018- 2019 .Out of total 4,22,000 flowering plants reported from the world more than 50,000 are used for medicinal purpose.Iman M.Ahmedet,el.Dathura aqueous leaf extract enhance Cytotoxicity via metabolic oxidative stress on different human cancer;Ali M. and Alam
P.Worked on physiochemical investigation of calatropis proceraroots,Khan,A.Q. and Malik worked on a new pentacyclic triterpine from calatropis procera,Dey P.Roy and Chaudhri T.K. reported a quantitative assessment of bio active phytochemicals of Nerium indicum,Odhia P.M.worked on clinical use of Congress weed Parthenium hysterophorus.

\section{METHODOLOGY}

The ethnobotanical survey was conducted during 2018- 2019 among the five tribal communities. Elder people, medicine men, tribal physicians and village old mothers were consulted to record first hand ethnomedicinal uses of poisiounous plants, methods of preparation and administration of the crude drugs. The information from the tribal people was compared with literature. The voucher specimens were deposited in the herbarium of Department of Botany,J.M.Patel College Bhandara.

\section{Enumeration}

1. Botanical Name:Datura strmoruium Vernacular Name:Dhatura Family: Solanaceae 
- Phytochemical Constituents :

Alkaloids including, atropine, hyoscamine and scopolamine, sixty four tropane alkaoid have detected from $D$. strmoruium.

Medicinal Uses :Antiasthmatic activity,Antimicrobial,Anti Cancer,Anti fungal ,Anti Viberocidal

\section{Botanical Name :Calotropis gigantean}

Vernacular Name:Aak,Madar

Family:Apocynaceae.

Phytochemical Constituents :

Phytochemically the plants has been investigated for cardenolides from the latex \& leaves

terpenoids,Sugar,tannins, alkaloids,saponins and anthocyanins from flowers.

Medicinal Uses :

Calotropis has shown some activity against pain, inflammation, bacterial fever \& ulcers caused by alcohol and medication such as aspirin. It has analgesic, hepatoprotective activity, antidiarrhoeal \& antidiabetic, antiinflammatory, antimicrobial, antifertility \& anti oxidant activity

3.Botanical Name:Nerium indicum

Vernacular Name:Kaner

Family:Apocynaceae

Phytochemical Constituents :

Various parts of Nerium. indicum shows presence of wide range of phytochemicals such as phenolics, glycosides, alkaloids, tannin, flavonoids etc.

Medicinal Uses :

Despite the danger, seeds and leaves are used to make medicine. It is used for heart conditions, asthma, epilepsy, cancer, painful menstrual periods, leprosy, malaria, ringworm.

4.Botanical Name:Parthenium hysterophorus

Vernacular Name: Congress grass

\section{Family:Asteraceae}

Phytochemical Constituents :

Leaf extract was studied for the presence of carbohydrate, alkaloid, steroids, glucosides, tannin, phenolic compound, saponin, falvonoid oil.

Medicinal Uses :

Regular contact with the plant produces allergenic dermattis \& asthma in humans. But used in many medicinal treatments of skin inflammation, rheumatic pain, diarrhoea, urinary tract infection, dysentery \& neuralgal.

5.Botanical Name:Sphaeranthus indicus

Vernacular Name:Gorakhmundi

Family:Asteraceae

Phytochemical Constituents :

Showed the presence of carbohydrate, proteins, amino acid, tannins, phenols, steroids, saponins alkaloids and flavonoids.

Medicinal Uses :

Sphaeranthus indicus is widely used in ayurvedic system medicine to treat epilepsy, mental illness, jaundice, hepatopathy, diabetis, leprosy, fever cough, hernia, dispepsia and skin disease.

\section{RESULT AND DISCUSSION}

In the present survey we found many poisonous plants but in all selected 05 species of Poisonous plants for Medicinal use, five families have been identified and recorded from the area ofBhandara region Commonly used for medicinal purpose. So far from the above data the plant that use in the digestive, respiratory, circulatory and neurological disorders.Used to treat fevers, elephantiasis, nausea, vomiting, and diarrhea, arthritis, cancer, and as an antidote for snake bite, hydrophobia, epilepsy, convulsion, syphilis, inflammation of the breasts, smallpox, mumps and leprosy, asthma, cough, malaria, ringworm, indigestion, and venereal disease; Painful menstrual periods, Cause abortions, skin problem, allergy, mental illness, hemicrania, jaundice, hepatopathy, diabetes, fever, pectoralgia, gastropathy, hernia, hemorrhoids, helminthiasis, dyspepsia and were the other prominent problems. The parts of 
majority of plants identified used were fruits, leaves and root.

\section{CONCLUSION}

Every plant is a great source of chemical compounds. But the lack of information and proper knowledge make it impossible of their proper use. The recent literature makes it evident that this considerable gap in the knowledge of poisonous plants persists and a lot to be explored. Traditional knowledge may occur by chance and by trial. The potentiality of ethnophyto toxicological investigations would lead to the discovery of some new eco friendly management of diseases and pests and other bio-drugs. Therefore a detailed biochemical, pharmacological study and systematic survey of such poisonous plants should be carried out in more areas of our country for their proper utilization, conservation and maintains of biodiversity.

\section{REFERENCES}

Ayyanar M., Ignacimuthu S.; 2005. Traditional knowledge of kani tribals in Kouthala of Tirunelveli hills, Tamil Nadu, India. J. of Ethnopharmacology. 102:246-55.
Badgujar S.B., Patil M.B. (2008).Ethnomedicines for jaundice used in tribal areas of North MaharastraNat Procd Rad,7(1): 79-81.

Balakrishnan V., Ravindran K. C., Robinson J. P.; 2009. Ethanobotanical studies among villegers from Dharapuram Taluka, T.N., India. Global J. of Pharmacology 3(1): 08-14.

Hooker J. D.; 1875. Flora of British India.1(7): L. Reeve \& Co Ltd., England.

Kamboj V. P.; 2000. Medicinal plant. Curr. Sci 78 (1): 35-39.

Samant S.S., Dhar U. and Palni L. M. S.; 1997. Medicinal plants of Indian Himalaya Diversity distribution and potential Value Nainital. Gyanodaya prakashan.

Yadav S.S. and Patil S.H. (2000). Traditionamedicines and health care system of tribals of Satpuda region, Maharastra State, New Botanist, 27(1): 51-65. 